\title{
Translation
}

\author{
JUAN ANTONIO INAREJOS
}

\section{"Moral Influence" in Asia Political Practice and Electoral Corruption in the Spanish Philippines}

Proceeding from a microhistory of local elections at the end of the nineteenth century in one municipality, this article traces the mechanisms of representation and exercise of local power in the Spanish Philippines. Within the colonial apparatus the municipal sphere was one of the few areas of tangible power for the principalía (indigenous elites). The local elites, who were selected by colonial authorities based on political, economic, and religious criteria, played an important role in the fealties and resistances in the colony. This article examines the significance of the Maura Law, or the electoral reforms of 1893, and the obstacles encountered in the eradication of electoral abuse-"moral influence"-that colonial authorities, through action or inaction, had promoted over the years.

\section{KEYWORDS: MUNICIPAL ELECTIONS - REFORMS - LOCAL POWER -} NATIVE ELITE · SPANISH COLONIALISM 
$\mathrm{n}$ the middle of the nineteenth century the moderate liberal Luis María Pastor (1863) published a work entitled Las elecciones, sus vicios. La influencia moral del Gobierno. Estadísticas de la misma y proyecto de reforma electoral (Elections and their Vices. The Moral Influence of Government: Statistics from the Same and a Project for Electoral Reform), in which he cataloged some of the most recurrent artifices used by administrations of the mid-nineteenth century in the falsification of electoral results in Spain. The text also popularized the use of the euphemism "moral influence" in reference to governmental intervention in electoral processes. The term became a useful formula for presenting executive interference as a purely moral question that-with the objective of covering up the thoroughly institutionalized interventions that indeed occurredmediated the autonomy and direction of the vote. Pastor's reflections on the parameters and conditions that should govern state intervention in elections were a clear example of a doctrine that extended across the political cultures of "respectable" nineteenth-century liberalism, one which saw social and political influence as a tolerable and commendable element when intervening in electoral processes and canalizing political representation.

The political practices and the consequences that arose from this doctrine have been the subject of numerous studies focusing on the origins and configuration of liberal caciquismo from the commencement of the reign of Isabella II up to the Restoration. However, little attention has been paid to the application of these conceptual categories to an analysis of the systems of imperial domination deployed in the Philippines during the nineteenth century. As such, I propose to examine how such a conception of political representation affected the elections of gobernadorcillos: the only tangible level of power attainable by the indigenous population within the colonial political-administrative apparatus. I also propose to trace the determining factors for the administration of a greater or lesser "dose of moral influence," the relation of this "dosage" to the political moment, and the specific conditions that had a bearing on the native population, such as disagreements between factions or families, the presence of Spaniards, the extent of the social and cultural roots of given candidates, and the interest and coercive capacity of the governing colonial authorities. Through such an analysis I intend to evaluate the real scope and significance of the 1893 reforms in relation to the corruption that had effectively rendered meaningless the elections held to grant local power to the indigenous population. This article, then, is a microhistorical study located around the end of the nineteenth century, a time when the colonial authorities redoubled their efforts to control the levers of municipal power within a context marked by the increasing contestation of Spanish rule, the first push of incipient Philippine nationalism, and international imperialist expansion. ${ }^{1}$

\section{The Indigenous Principalía as}

\section{a Sphere of "Moral Influence"}

The Constitution of 1837 formed the Government of the Philippines under some initially transitional Leyes Especiales (special laws). These laws, with the exception of the ethereal and progressive elements it contained due to the periods of observance of the 1812 Constitution and the influence of postFrench Revolutionary reforms, diminished the political rights of the entire citizenry of the island territories. ${ }^{2}$ The only sphere of representation was limited to the election of the gobernadorcillo, a form of town mayoralty. As a diminutive of the Spanish for "governor," gobernadorcillo was effectively a deprecating and paternalistic term the use of which became common after 1696. It designated an authority over indigenous populations and the existing chiefs of the barangays in individual villages. Of noble origin, the roots of the barangay chiefs could be traced back to the heads of the different prehispanic familial and territorial groups of the same name. The cabeza de barangay (barangay chief) stood as the head of a group of tax-paying tributaries that could live in different neighborhoods. Hence, the barangay was not a spatial division of the municipality. ${ }^{3}$ Forming a hierarchical nucleate of populations, these socioeconomic organizational structures were integrated into the new colonial system. The position of barangay chief was hereditary and lifelong (a privilege that did not prevent the Spanish authorities from appointing other chiefs) until, in 1789, the position was filled through election. As with the gobernadorcillos, the barangay chiefs had wide powers over public order and taxes; they enjoyed certain privileges such as exemptions from personal, military, and tax duties. In sum, the colony was administered by a mixed political-administrative system that intercalated direct and indirect mechanisms of power. ${ }^{4}$ The colonial rulers did not supplant these prehispanic indigenous elites, also known as principales; rather, they ceded the reigns of local power and delegated new responsibilities to them. ${ }^{5}$

Until the Maura reforms of 1893, the elections that took place in the second half of the nineteenth century were governed by the regulations 
of $1847 .{ }^{6}$ However, both these regulations were but modifications that introduced some variants relating to the selection of gobernadorcillo candidates. In effect, the system remained largely unchanged until US intervention beginning in 1898. Among the barangay chiefs who formed each group of principalia, lots were drawn (biannually from 1862 onward) to choose twelve "electors." These twelve electors and the outgoing gobernadorcillo comprised the thirteen who were charged with electing a terna, or a "council of three," formed by those who received the highest number of votes - a significant sifting process that allowed insight into the level of current consensus among the indigenous elites. ${ }^{7}$ This result was transmitted to the civil governor of the province, who then submitted to the Philippine governor-general the name of the member of the "council of three" whom he considered to be the most suitable for the post. Alternatively, the civil governor could annul the vote. In making his decision the civil governor had at hand detailed and exhaustive reports sent by different Spanish authorities (such as the civil guard, parish priests, and the administrator of the treasury) concerning each member of the "council of three." The reports covered political, economic, and religious aspects of governance.

The system had been undermined by the corruption of the indigenous elites who contested the power, compliance, complicity, or protection of the religious orders and the Spanish colonial authorities. ${ }^{8}$ During the brief period in which they were in force, Maura's reforms of 1893 had a number of aims. ${ }^{9}$ In the first instance the reforms were supposed to be a new attempt to rein in electoral abuses. The growing peninsular and international interest in the Philippines brought with it attempts to rationalize, modernize, and regenerate the colonial administration in order to strengthen ties and build new bridges with the metropolitan government. ${ }^{10}$ In the second instance, the new legislation sought to increase the power and participation of the local propertied classes. Attempts were made to generate fealties among the indigenous elites within a situation marked by the growing tide of contestation of Spanish colonial rule. ${ }^{11}$

The elasticity of the category of principal-as an individual within the principalía - is based on one of the main changes introduced by the Maura Law of 19 May 1893: any resident who had paid a fifty-peso "territory tax" could acquire the status of principal. This measure was no mere formality; rather, it had significant repercussions within the electoral body that was charged with selecting the capitán municipal (municipal captain)-a term designed to replace the pejorative gobernadorcillo (Sánchez 1991, 367). The new modifications in the electoral system did increase the number of voters who had access to the electoral process. The primary change in electoral participation was the concession of three votes to those who were not barangay chiefs but had "contributed" the most in the local area. These three voters, together with the old gobernadorcillos and the barangay chiefs (with three and six votes, respectively), formed the new electoral body whose members were called "delegates."

The capitán municipal began to preside over the elections in conjunction with the parish priest-a move intended to eradicate the influential presence of the civil governor or of his delegates during the voting process. That it was precisely the provincial governor who saw his capacity for manipulation and intervention greatly reduced was no small matter, primarily because his central position in the previous system had been replaced by direct and unipersonal election in the hands of the new electoral body. The influence taken away from the provincial governor was passed to the new capitán municipal, who expanded his responsibilities with new incumbencies aimed at reinforcing his authority and prestige. In this regard two questions arise. What was the true effect of this new legislative arrangement? Did these reforms, in the brief period in which they were in force, eradicate the electoral abuses that had been repeated for decades?

\section{Electoral Reforms and the "Moral Influence" of the Civil Governor}

An examination of the contested elections that involved the principalía of San Isidro de Tubao, in the province of La Unión in Luzón, allows us to see clearly the practices, justifications, objectives, and consequences of electoral corruption in the Philippines. By extension, it also allows us to view the opposition encountered by the colonial authorities when they attempted to eradicate the corruption that they themselves had promoted and tolerated. Some of these manipulations are known from the complaints brought to the attention of the governor-general. The municipal delegates of San Isidro complained that the election held on 23 November 1894 failed to comply with the new legislation regarding municipal elections. A dispatch to the governor-general was the main leverage behind the protest. It enumerated in great detail the abuses that had dominated the elections, a list of which was preceded by an extensive preamble. 
Que amantes sinceros del bien moral y material de su pueblo, y por lo mismo, deseosos de que quién haya de regir y tener en sus manos el principal cargo municipal de la población y ávidos porque la ley se cumpla con toda rigidez, en fin, porque no pueden consentir que las elecciones municipales celebradas en su pueblo San Isidro se practiquen con infracción completa de los reglamentos sobre régimen municipal ... pues se consideran muy lastimados en el proceder demostrado por el señor Gobernador Civil de la provincia de La Unión ... Un breve, escueto y verídico relato que de cuanto ha ocurrido en aquellas elecciones han de hacer aquí los recurrentes, convencerá íntimamente a V. E. de la justicia de esta respetuosa queja y de la legalidad y procedencia de la súplica que han de formular.... ${ }^{12}$

That those sincerely desirous of the moral and material good of their people and, in the same manner, desirous that whosoever should rule, having in his hands the primary municipal responsibility for the population should fulfill that responsibility, and hopeful that the law should be complied with the greatest rigor, cannot, in the end, permit that the municipal elections in the town of San Isidro be carried out with the complete infraction of the regulations concerning municipal governance ... these regulations are considered greatly damaged by the self-interest manifest in the actions of the Civil Governor of the Province of La Unión.... The appellants provide here a brief, unembellished, and truthful account of what occurred in those elections which will, in your heart, convince Your Eminence of the justice of this respectful complaint, and of the legality and appropriateness of the petition which they are to formulate...

Beyond the hyperbolic language and the power struggles alluded to in this complaint, in many such cases of appeal to legal defense and the common good the governor of the Philippines would analyze the contents of the complaint and corroborate the truth of the accusations. The three signatory delegates of the principalía-spokesmen in turn of four other delegates, seven in total, i.e., the majority of an electorate composed of twelve electors - were Bernardo Dacanay, Alberto Boadoy, and Torcuato Gago, all natives and residents of San Isidro de Tubao. At the same time they were spokespersons for their fellow delegates Buenaventura Dacanay,
Dámaso Suguitán, Domingo Fortes, and Emeterio Padilla. Of these, only the first, Bernardo Dacanay, was elected delegate by dint of his status as a major taxpayer. According to the informants, the abuses that had undermined the election had rendered the vote null and void. ${ }^{13}$ The primary reason for this was the presence of the civil governor himself during the electionthe only one he had supervised of all the local elections in the province. His presence violated the legislation passed on 19 March 1894, which established a municipal regime for the towns in Luzón and the Visayas that had counted more than 1,000 cédulas or "registered inhabitants." ${ }^{14}$ Article 4 of this legislation (complemented by Article 21 of the provisional regulations concerning the execution of the previous decree) had ended the decisive presence of the civil governor during the election, with his sole role reduced to naming the election date.

José María Osorio, civil governor of La Uniòn, himself coerced the delegates to elect his candidate, Carlos González, as capitán municipal. Nevertheless, seven delegates paid no heed to the "recommendations" of the governor and cast their votes in favor of Miguel Halog. Halog was described by his supporters as "a person without any legal blemish for such a post, an honorable resident and principal, and furthermore one of the wealthiest men of San Isidro" (persona sin tacha legal alguna para tal cargo, vecino y principal reconocidamente honrado y para mayor abundamiento uno de los más pudientes de San Isidro). Such testimony revealed another constant factor in the legitimation of political power in the Philippines: wealth as an important source of social power. ${ }^{15}$ Hardly had Osorio heard firsthand the adverse result of the vote when he unilaterally annulled the result and called a new election on the subterfuge that his candidate spoke Spanish - a qualification that Halog did not meet. Once again language, far from constituting an indispensable requisite for public office, was instrumentalized by the authorities in order to select candidates according to their own individual interests. ${ }^{16}$ Indeed, under the new regulations, the local priest as spiritual authority was allowed to be present at the polling place as translator, to attend the primary vote, and announce the result. ${ }^{17}$ When the cleric retired to dine at the monastery, the civil governorhaving declined the priest's invitation to lunch-used the priest's absence to pressure the electors, with the help of his secretary and the "European Spaniard" Felipe Santiago González, justice of the peace of San Isidro and father of the governor's candidate. ${ }^{18}$ The elder González used this authority 
to heighten intimidation: he threatened to open criminal proceedings against the seven delegates who had voted for Halog. Terrified, the former "rebels" allowed their arms to be twisted and cast their votes in a second round in favor of the official's son, Carlos, in an election described euphemistically as "unanimous." 19

The complainants wrote in protest to the governor-general to defend themselves against the attacks by the civil governor and denounce the coercion perpetrated by the justice of the peace..$^{20}$ They tried to refute the linguistic impediment attributed to Miguel Halog, the winner of the first round of elections. The civil governor stated that, although Halog could understand Spanish, he could neither speak nor write the language. But this inability was no insurmountable obstacle to his ascending to the post. According to the complainants, notwithstanding Article 9 of the 1893 regulations stipulating that the capitán municipal should be able to speak and write Spanish, Article 49 of the same legislation stated that the session records of the municipal tribunal-regardless of the attendance of the parish priest and the principalía delegates - should be written in Spanish if all those who were to ratify them understood the official tongue. Should this not be the case, the session records were to be written in Spanish and translated to the native language. As such, according to the complainants, Article 49 circumscribed the language requirement of Article 9-an argument that was reinforced by a municipal secretary who translated the decisions and consultations in Spanish for the benefit of the capitán municipal and other members of the municipal council. The complainants tried to present the language problem as a subjective question as they recounted the "displeasure" shown by the civil governor when, upon arriving in the area, he learned that the inhabitants spoke no Spanish. ${ }^{21}$ The civil governor failed to take into account the special circumstances that prevailed among this principalía: the town was only six years old, located in a mountainous terrain, with only rudimentary infrastructure, and a population composed of migrants from different parts of the country. ${ }^{22}$

The original voting slips in the first round of elections had to be attached to the transmittal documents, in line with the guidelines set by Governor-General Weyler on 20 February 1890 in order to prevent electoral manipulations. Nevertheless, as was corroborated by the parish priest, the capitán municipal refused to include the written protest in the electoral minutes, which prompted him to send it directly to the governor-general.
The transmittal of the electoral results should have included a report by the parish priest concerning the abilities of the two candidates. In the case of San Isidro the priest had taken the side of Halog on account of his abilities, his personal history, and his civic responsibility - but this report was also not attached to the electoral minutes. The priest's report contradicted the language argument raised to discredit Halog in that it assured that Halog's Spanish was adequate and he was fluent enough to carry out the duties of the post. Similarly, the report called into question the mestizo Carlos González's prime "assets" when it stated that he spoke Spanish "fairly imperfectly." In his report, the priest backed the delegates' accusation and added new material concerning the corrupt practices of the elder González. The priest mentioned bribery as one of the means employed in González's attempt to secure for himself the reins of power. The priest also brought to light previous complaints of abuses committed by González during the latter's term as a barangay chief and justice of the peace. Such abuses had aroused the animosity of many residents - the same ones who were pleased that the younger González had failed to win the elected post. The breach between the priest and the civil authorities (the provincial governor, the capitán municipal, and the justice of the peace) was more than evident.

Such imputations did not stop there. The complainants-upholding Articles 9 and 16 of the 19 May 1893 decree-stated that the candidate imposed by the civil governor did not fulfill the legal requirements of the post for which he was designated. According to the regulations, only naturales (indigenous natives) and Chinese mestizos could become barangay chiefs and municipal captains. Carlos González, barangay chief of San Isidro during the previous four years, was the son of the peninsular Spaniard Felipe Santiago González and a native woman of Agoo, making him a "Filipino Spaniard." As such, he was ineligible to hold the position of barangay chief and, by extension, that of capitán municipal. Furthermore, he had been unable to attend the election as he was unwell, an absence that meant he could not vote nor be voted for.

Finally, in order to persuade the governor-general and avoid the building of a power bloc within the principalía, the delegates brandished an informal, extraofficial consideration of the González family's character. They reminded the governor-general that Felipe Santiago González, a European Spaniard who had resided in San Isidro for many years, not only held the post of justice of the peace but was also the agent of the tobacco 
company Compañía General Tabacalera. ${ }^{23}$ In this case, if in the end his son was named capitán municipal, he would have his hands on the levers of gubernatorial, judicial, and municipal power, a situation that understandably would give rise to the arbitrary authority of a single will. Here again was another testimony that shed light on the interests of local elites who, directly or indirectly through front men, ostentatiously held on to these posts in order to defend or promote their own economic interests. ${ }^{24}$ This begged the question: Were the highest colonial authorities prepared to agree to this sort of amalgam of power? In the end, Manila annulled the elections. However, the order to repeat the vote made no attempt to prevent the configuring of a client network that would combine economic, administrative, and political power; rather, the governor-general's reasons for invalidating the electoral process had other motives.

On being informed of the challenge to the elections in San Isidro, the governor-general in Manila ordered an investigation into the reported electoral fraud, a task given to the director-general of civil administration. On 3 April 1895 he urged the civil governor of La Unión to corroborate immediately and categorically as to whether Capitán Municipal González had violated the clause that reserved this post for naturales and Chinese mestizos. Five days later he requested the provincial vicar of La Unión to provide a birth certificate for Carlos González to aide in the investigation. ${ }^{25}$ At the same time, he demanded that the civil governor submit the original electoral minutes. In these minutes the existence of any protest had been denied and the legality of the election simulated, stating that the election "was carried out in accordance with the Royal Decree of 19 May 1893 , complying with all formalities, and with neither protest nor complaint worth reporting to Your Eminence ..." The first round of voting in which González was defeated was omitted; only the "unanimous" result of the second (and mediated) round was mentioned. Here, one finds striking parallels with the common irregularities that dominated nineteenth-century elections in Spain. However, the possibility of resorting to alternative channels to expose such irregularities, such as the press or parliamentary tribunal, was greatly reduced in the case of the Philippines in contrast to the Peninsula.

On 8 May 1895 the governor-general informed the civil governor of La Unión that the director-general of civil administration had annulled the elections that took place in San Isidro in November 1894. However, it is important to look into the reason for this nullification. The correspondence between these two authorities revealed that the central issue they identified was Carlos González's "legal incapacity" arising from his status as a "Filipino Spaniard." The naturales and Chinese mestizos were not only excluded from exercising their political rights as citizens, or entering into the higher levels of colonial administration, ${ }^{26}$ but the few spheres of power that were reserved for them had also been usurped by Peninsular Spaniards, thanks to the complicity of the colonial administration. ${ }^{27}$ In this regard the careers of members of the González family were fine examples of such asymmetric interference. The mestizo "Spanish Filipinos" of the first generation had rights equivalent to "Europeans" or "Peninsulars." In comparison with the analogous situation in Latin America, such mestizos comprised a far smaller percentage of the total population of the Philippines. ${ }^{28}$ Both cases explain the rarity of demands such as those generated, for example, by the French Indochina mestizos in relation to the dichotomous contexts of citizenry among the metropolitan French and their colonial subjects. ${ }^{29}$ Such demands would indeed become connected with those supported by the more deeply rooted Spanish mestizos and by the more numerous Chinese mestizos, ${ }^{30}$ two of the principal mainstays of the incipient colonial bourgeoisie, who would play a determining role in the creation and crystallization of a Filipino nationalist discourse (Elizalde 2002, 123-42). ${ }^{31}$

With the attention focused on Carlos González's "legal incapacity" to hold office, other fraudulent activities carried out by the civil governor during the election-despite being widely known - were omitted. ${ }^{32}$ Furthermore, in the abovementioned document, the Department of Civil Administration tried to exculpate the elder González on account of an alleged lack of knowledge as to his status:

De la sumaria y verbal instrucción efectuada, resulta plenamente comprobado que, si bien el acto electoral se verificó ajustado a la ley, fue en él electo como Capitán municipal Carlos González, cuya elección quedó aprobada por el Gobernador Civil de la provincia por desconocer que el citado González tenía la condición personal de ser español filipino y no la de indígena o sangley que la ley determina para servir dicho cargo. Conocida que fue esta circunstancia por el referido señor Gobernador, se dispuso a anular la aprobación, resolviendo al mismo tiempo se procediese a una nueva elección para cubrir la vacante que el González deja. 
It is clearly proven in the summary and verbal instruction carried out that, if indeed the election was carried out in accordance with the law, Carlos González was elected as capitán municipal. His election was approved by the Civil Governor of the province in ignorance of the fact that Carlos González was a Filipino Spaniard and not indigenous or Chinese [mestizo] as determined by law for this position. As the Civil Governor came to know about this fact, he withdrew his consent and decided to hold a fresh election in order to fill the post left vacant by Carlos González.

In addition to calling for a fresh election, the same circular of 8 May indeed sought an explanation from the civil governor regarding the reasons that had caused him to dismiss the barangay chiefs of San Isidro: Buenaventura Dacanay, Emeterio Padilla, Guillermo Fortes, Dámaso Daguitán, and Alberto Boadoy. It was no coincidence that they were five of the seven delegates who had challenged the first election. The hypothesis that these dismissals comprised a reprisal gains strength when the apologies the civil governor presented before his superiors are studied. In the first instance, these apologies were related to his post. He apologized for having repeatedly failed to fulfill his duties, for abandoning his post without the requisite permission to leave the district, and for concealing tax penalties. In the second instance, he apologized for revoltosos en el distrito, which is to say, for "questionable conduct within his district."

To back up his assessment, the governor added the "objective" report from Justice of the Peace González, the father of the official candidate. Buenaventura Dacanay-described by the governor as one of the ringleaders, "a plotter, and a man of ill conduct" - was accused of "rebellion" for bringing documents of protest before the authorities and inducing others to sign them. Furthermore, Dacanay had presented himself as a candidate in all the gobernadorcillo elections that had taken place in San Isidro since its creation as an independent town. ${ }^{33}$ From these testimonials it was clear that the sheer fact of having raised a protest, denounced irregularities, and participated in elections had stigmatized him in the eyes of the colonial authorities. ${ }^{34}$ From this we can question the typifying of colonial societies in terms of slothfulness, disinterest, and lack of motivation. ${ }^{35}$ In 1892 and 1893 Dacanay had occupied the post of gobernadorcillo, a two-year period that, according to Justice of the Peace González, was marked by a sentence of thirty days to which he was punished for disobeying the priest (who had since died and was succeeded by the priest who had censured the electoral irregularities). During his tenure as head of the principalía, Dacanay had as his aide a certain Guillermo Clemente, who had been imprisoned for "filibustering" - a vague term that became popular, following the publication of the excoriating late-century novels of José Rizal. "Filibustering" became a byword among the Spanish authorities (alongside others such as Rizalistas) to describe a wide and diffused social and ideological spectrum ranging from those who merely sought colonial reform to those who openly defended the cause of Philippine independence. The term filibustero is comprised within a broad catalog of similar labels whose extensive use called into question the supposed lack of previous indications on the part of the colonial authorities regarding the insurrection of $1896 .^{36}$

In other instances opposing factions used these labels as accusatory levers to demonize their rivals before colonial authorities. The report by the judicial authority stressed that Guillermo Clemente was the son-in-law of Adriano Novicio, who had participated in an uprising that took place in Pangasinan. ${ }^{37}$ Similar profiles were presented for the other complainants. Guillermo Fortes and Emeterio Padilla - who, during Dacanay's two years as gobernadorcillo, had occupied the positions of deputy mayor and juez de ganados (livestock judge), respectively - were noted as having been tried for falsifying documents. Dámaso Suguitan and Alberto Boadoy (along with the above) were labeled as under the sway of Dacanay and in a "patronage" relationship with him.

In order to compare these reports with others concerning people who were not within the patronage of the official candidate, the director-general of administration requested a report from the new parish priest concerning the dismissed delegates. Despite the system of the "council of three" having been formally dispensed with in the new electoral legislation, its underlying procedures, such as the reports on conduct, continued informally, especially in elections that were investigated due to irregularities. However, the priest had only been recently appointed and, as such, was unaware of the previous period during which Dacanay and his followers had controlled the principalía, a time marked by the confrontation between Dacanay and the former parish priest. ${ }^{38}$ Nevertheless, the new priest came to a conclusion completely opposed to that of Justice of the Peace González: the priest had found no punishable offense. On the contrary, he noted the loyalty, respect, 
and obedience of these councilors and criticized their dismissal from the posts they held. Furthermore, he tried to downplay the accusations of the justice of the peace, recognizing that such behavior was common among barangay chiefs of other neighboring principalías and considered by the Spanish as "typical" behavior by the "natives." 39 The failure to bring them to trial was imputed to "pressure and influence being brought to bear by other persons in their sphere." The new priest's aim was clear: to present the dismissed delegates as merely functionaries or front men in order to depoliticize the affair and remove the ideological aspect of González's report, which had intended to stigmatize them in the eyes of the higher authorities.

In July 1895 the new civil governor ratified the priest's assessment on account of the verbal testimonies he had managed to obtain in the few days he had been in his post. Several months had already passed since the elections, and Chief of Police José María Osorio-accused of orchestrating the manipulated result, and the very person who had verified the credibility of González's report and instigated investigations on the irregularities he himself had encouraged-had been replaced. The inquiries by the authorities led the governor-general to declare the electoral results null and void and reinstate the dismissed delegates. Such a procedure demonstrated the way in which the colonial authorities, rather than being concerned with the interventions themselves, were disquieted by how public opinion would view such interventions. Throughout the months of the investigation, the Manila authorities censured the manipulations of the civil governor. The department tasked with the proceedings acknowledged that the postelection dismissals of the delegates came about due to "tensions" that arose at the heart of San Isidro's municipal body over the election for the post of capitán municipal. This election suffered "certain vicissitudes," with the terms "tension" and "vicissitude" serving as euphemisms for "reprisals" and "fraud," respectively.

Electoral corruption in the Peninsula was treated in a remarkably similar manner. Referring back to Luis María Pastor $(1860,57)$, we see that he tried to avoid "upheaval" and "disorder." For this reason the protesting indigenous delegates in particular were demonized. When the level of coercion increased and became more common, the authorities hastened to take measures intended to cloak the electoral process with pseudolegalism. Although in a few and exceptional cases election results that were evidently manipulated were annulled, in the majority of cases merely symbolic measures were taken, or hollow promises were made with the intention of giving the electoral process a façade of legality and temporarily silencing the criticisms of the aggrieved parties. ${ }^{40}$ This was especially so at the juncture when the disaffection of the indigenous elites toward Spanish rule had begun to be seen as significant. It is noteworthy that the civil governor was replaced surreptitiously - despite the fact that no explicit mention was made of this move-which rendered him the scapegoat for the corruption of the electoral process. ${ }^{41}$

\section{Local Power: The Diminishing of the Capitán Municipal}

Despite the discrete replacement of the civil governor, electoral manipulations did not cease. The complicit municipal sphere had not been reformed, and scarcely had a new vote taken place when the machinations to falsify the result were redoubled. One of the aims of the 1893 reforms was to shore up the authority and prestige of the devalued post of capitán municipal. Nevertheless, this symbolic and functional strengthening of the office formerly titled gobernadorcillo left it susceptible to being diminished, and the new elections that were called in San Isidro provided a clear example of this failure. Once again, corruption was to be reported directly to the governor-general by the same group of delegates that had raised the first protest.

Que con harto pesar y hasta con miedo elevan su humilde voz a V. E. para poner en su elevado conocimiento hechos que su justicia y rectitud bien conocidas no podrán menos de calificar de ilegales, que así los encuentra la corta inteligencia de los exponentes: y al elevar este respetuoso recurso de queja tienen por móvil el deseo que las prescripciones legales, o los Reglamentos autoritativos sean una verdad práctica en esta localidad, que no sean atropellados por las personas que los deben acatar y cumplir, porque los recurrentes tienen la íntima convicción de que V. E. querrá saber cuánto pasa en este lejano pueblo referente a los actos públicos de la autoridad para en su caso anularlos y castigar a los agresores de la ley que con sus actos punibles dan ejemplos fatales y de trascendencia en la moralidad pública. . .

It is with a heavy heart, and with a measure of fear, that we raise our humble voice to Your Eminence, to make you aware of some deeds 
the justice and rectitude of which, once known, cannot be qualified as anything but illegal, as they are deemed in our scant understanding as expositors. The purpose of this respectful complaint is to see the legal prescriptions, or the authoritative regulations, serve as a practical truth in this locality; that they are not trampled upon by those persons who ought to respect and uphold them. We the appellants are intimately convinced that Your Eminence wish to know the events in this distant town regarding the public acts of those in authority in order to annul the result and punish the transgressors of the law who by their actions set a significant and dangerous precedent in public morals....

The submissive and self-deprecatory language deployed by the complainants-their "humble voice," their "scant understanding," expressions repeated with tiresome insistence throughout the text-was revealing. Similarly symptomatic was the fear of probable reprisals, either formal or informal, that could arise from the act of denouncing electoral corruption. The mention of their fears was no empty talk: they had the recent experience of the first contested elections and the reprisals that occurred in the form of their dismissals. The calling of new elections was marked by the appointment of Deputy Mayor Agustín Ventura as provisional capitán municipal charged with organizing the elections ${ }^{42}-$ a position which, under the new reforms, came with a broad operational capacity and provided fresh opportunities for the emergence of new forms of corruption.

New elections were called by the civil governor for 14 May 1895. The delegates of the principalía gathered on the previous day ready to cast their votes. However, Agustín Ventura used his authority arbitrarily, ordering several of the delegates - the complainants, in fact-to present themselves at the provincial capital under armed guard. They arrived in San Fernando on 14 May, but the civil governor ordered them to return to San Isidro because there was no reason for them to be in the capital. By the time they reached San Isidro that same night, the election had already taken place. Ventura took advantage of the absence of the "rebellious" delegates to assure himself of victory as the new capitán municipal. ${ }^{43}$ The petition to the governor-general was signed by Torcuato Gago, Emeterio Padilla, and Bernado Dacanay, the three delegates who were sent to San Fernando to prevent them from being part of the electoral council. As they explained in detail to the governor- general, their absence reduced the electorate to eight voters (given that Buenaventura Dacanay could not attend due to illness), and the three absent votes might have swayed the results in the opposite direction. The minutes of the elections noted the complainants' absence without mentioning that they had been obliged to present themselves before the civil governor the day before. ${ }^{44}$

The absence of these three delegates from the election was a clear violation of Articles 5, 6, and 7 of the new legislation, which stated that the electorate had to be comprised of twelve members. By extension, the appointment of Ventura to the elected post was invalid. The irregularities did not end there. Four of the five delegates who voted for Ventura-the same ones who had supported Carlos González in the previous "unanimous" election-were ineligible to exercise their right to suffrage. Felipe Santiago González was the justice of the peace in San Isidro and a European Spaniard, contravening the legislation on two counts: firstly, the incompatibility of his current post with membership of the electoral council; and, secondly, his violation of Articles 9 and 16 of the 19 May 1893 decree, which stipulated that no one who was not of indigenous or Chinese mestizo descent could hold a municipal post. The barangay chiefs Anselmo García and Florentino Milans were brought before the court accused of illegal gambling, when they were deputy mayor and teniente de cuadrilleros (municipal civil guard), respectively. Such an accusation corresponded to Article 16, which stipulated "evident probity" as a sine qua non for the position of barangay chief, a provision that also applied to the fourth of the ineligible electors, Santiago Vetía.

The ultimate irregularity in this case concerned the manner in which the protest itself was dealt with, that is, the conspiracy to impede it from reaching the higher authorities. The complainants had handed their written protest to the president of the municipal electoral council-Agustín Ventura himself-within the stipulated time frame for the submission of such complaints. Although Ventura had issued a receipt acknowledging this submission, there had been no corresponding response from the civil governor. Suspecting that the first administrative step had not been taken, the complainants appealed directly and "extraordinarily" to the governorgeneral. The regretful assessment by the administrative director-general concerning the claims of manipulation in the first vote was direct to the point, stating that this was the only protest that, having reached the civil governor, had been passed on to higher offices. In order to further legitimize 
and add credibility to their complaint, the petitioners reminded the Manila authorities of the "recent" annulment of the last election in San Isidro due to the corrupt activity on the part of the very faction that sought again to accede to the post of capitán municipal.

As in the investigation of the first election, a report was requested from the parish priest of San Isidro to verify the delegates' complaints. Here again, the informal recourse to the system of the "council of three" was made, a system supposedly eradicated by the reforms of 1893 . The priest, as his predecessor had done in the previous vote, threw his support behind the complainants and advocated the annulment of the election. Nevertheless, he sought to shield Ventura - schemer and benefactor of such ruses-from taking all of the blame, saying Ventura had perhaps received orders from the civil governor, or perhaps he acted merely as a conduit. Furthermore, the priest included fresh information concerning the contending factions, which had been omitted in the complainants' written protest. He accused the "Filipino Spaniard" barangay chiefs - referring to Carlos González_of setting a "bad example and lack of religiosity" and ridiculing the dismissed delegates and chiefs during his brief mandate as capitán municipal. The priest made clear that on account of his "patience and tolerance" he refused to publicly denounce González's behavior. He attributed González's conduct to his weakness and lack of "influence" relative to that exercised by the father, Santiago Felipe González, who was of European status and had the position of delegate on account of his contributions and "considerable fortune." To these credentials he added the elder González's support for, and complicity with, the town's "semi bandits" headed by delegate Anselmo García, who orchestrated the coercive acts of this faction and paid no heed to the admonitions of the priest. All of the above formed part of the same faction that had taken advantage of the absence of the priest to hold the elections and avoid the censure of their machinations - yet another snub of the parish priest, whose authority had been undermined by the regulations of 1893, which did away with the traditional reports of the parish priest on aspirants to the post of gobernadorcillo. Nevertheless, the priest's testimony allows us to question the commonplace proposition that the religious, colonial authorities, and Spaniards comprised a monolithic power bloc. In the same way, it allows us to see the complicities, denunciations, and censures that were implicated with the exercise of political, religious, and economic power in the Philippines.
Presided over by the civil governor, the provincial council unanimously decided to annul the election result because the number of delegates did not comply with the stipulated numbers. A fresh election was called, with the warning that all regulations were to be observed, given that this was to be the third election. Together with the decision was a statement by the chief of police that erased the doubts raised by the priest concerning his possible participation in electoral machinations. The governor distanced himself from the order that had brought the three delegates to the provincial capital on the day of the second vote, an action he censured for having harmed a just cause and which he tried to rectify by ordering the delegates to return immediately to San Isidro. Although the three delegates had arrived in San Isidro after the vote had taken place, the governor maintained that his action was sufficient to distance himself from the orchestrated irregularities. During the first election, his predecessor had used his position in the administrative body to defend those responsible for distorting the result before the higher authorities charged with the case. On this occasion the new governor solved the problem without the need for recourse to higher offices, whose responsibility in this instance was only the ratification of a decision already taken, and requesting punishment for the provisional capitán municipal who had ordered the departure of the three delegates. This punishment, ratified by the director-general of civil administration, took the form of his removal from the two offices he had held (those of provisional capitán municipal and deputy mayor) in order that, in the words of the civil governor, he might no longer be eligible to occupy the post again.

\section{Conclusion: The Failure of Reform}

Miguel Halog, the victor in the first instance, won the final election in San Isidro de Tubao. The electoral exercise occasioned no protests. The head of the rival faction, Santiago Felipe González, did not participate supposedly due to health problems - a symbolic act of disrespect toward the higher authorities in Manila, which highlighted the unease within the pro-Spanish faction about the failure to get their hands on the reins of municipal power. By rejecting the falsified electoral results and ceding local power to the faction that had placed the greater pressure on, and displayed the greater disaffection with, the colonial administration, the Manila authorities signified their option for an inclusive and integrative solution in order to avoid a profound disaffection with the electoral process, which could drive the native elites 
toward independence. The Maura Law of 1893 spearheaded an integrative strategy, but it would be eclipsed by the more repressive solutions that would predominate following the Revolution of 1896.

In short, the elections for the post of capitán municipal had to take place without the will of the voters being falsified by corrupt manipulations and with the new legislation seen to be effective. The successive elections held in San Isidro de Tubao were a clear indication - when it came to the recruitment and selection of the indigenous ruling elites - of the difficulties facing colonial authorities in eradicating the "moral influence" and vices that had accumulated over the years. Such activities and practices had come to be internalized by persons in the different levels of administration, the clergy, and the local elites. The reforms of 1893 sought to tighten the bonds between the colonial authorities and the indigenous elites, but without any step toward democratization being proposed. The elections in San Isidro de Tubao demonstrated how reality was often far from the ideals set by the law. The reforms failed to restructure municipal life and return the prestige lost by the local authorities. The new legislation gave greater autonomy to the municipal captain, but it did not lead to a real democratization of local power. The Maura Law itself was defined by two central issues: the brevity of its application, brought about by the commencement of uprisings against Spanish colonial rule, and the hindrances that it faced during its brief period of implementation as evinced by the elections in the province of La Unión.

\section{Notes}

This article, which underwent the review process of this journal, originally appeared in Spanish as "La influencia moral en Asia. Práctica política y corrupción electoral en Filipinas durante la dominación colonial española" in the Anuario de Estudios Americanos 69(1): 199-224. DOI: 10.3989/aeamer.2012.1.07. The author thanks Courtney Johnson for assistance in the translation.

1 This study is an initial result of a more ambitious study of the nation-building process and mechanisms of political representation in the Philippines during the nineteenth century. It is based on documents from the Philippine National Archives, Manila, which have been copied and are now housed in the Centro de Ciencias Humanas y Sociales (CCHS) of the Consejo Superior de Investigaciones Científicas (CSIC) in Madrid.

2 This contradiction is discussed by Partha Chatterjee 1993 as the fragmentation of the nation. For a detailed analysis of this paradoxical legislation, see Celdrán 1994; Alvarado 2001, especially on the unconstitutionality of legislating by decree as a technique equivalent to a small "coup";
Fradera 2008; Blanco 2009, especially on the role the church played when it came to sanctioning this "apartheid," segregation, or colonial racism.

3 For more on this subject, see Sánchez 1990; Huetz de Lemps 1998a, 1998b.

4 To understand the case of the Philippines within the context of the various systems of direct and indirect rule undertaken by European powers in Southeast Asia, see Trocki 2004.

5 The establishment and development of the Spanish administration is the subject of detailed analysis in Hidalgo 1995. This history is synthesized in Alonso 2009.

6 The delegation of power and the legislative changes that governed local elections beginning with the conquest and continuing through the nineteenth century are outlined in the work of Sánchez 1991, 199-211, 354-76. Cf. Azcárraga 1871; Blumentritt 1881.

7 For details of the electoral process, see Owen 1974; De Jesus 1978; Sánchez 1989.

8 The struggles between families and native clienteles to seize municipal control are discussed in Inarejos 2011. I shall discuss the electoral interference by the religious orders in a forthcoming paper titled "Caciques con sotana. Poder e injerencia política de las órdenes religiosas en las Filipinas españolas."

9 For details of the reform, see Marimón 1994, 94-138; 1996. For the comparative case of Cuba, see Dunerin 1978.

10 This reinterpretation is underlined in Elizalde 2008; Rodrigo 2002.

11 For a concise summary of the wide range of factors that led to the uprising, see Castellanos 1998, 79-116.

12 Philippine National Archives (Manila), Series on Elecciones de Gobernadorcillos, La Unión, Legajo 112, rollo 6443, CSIC Madrid.

13 The three informants were Bernardo Dacanay, Alberto Boadoy, and Torcuato Gago.

14 The tax of cédula personal, created in 1884, combined several existing personal taxes. Given its function as a public security and personal identity document, its issuance was not immune from manipulations and irregularities during the short span of its use. Measures taken to rationalize public finances during the nineteenth century, the work of tax collection agents, and the role of the personal tribute, and all mechanisms put in place by the colonial administration, are carefully analyzed in Fradera 1999, 133-90.

15 Also of particular consequence was land ownership, as has been noted in the classic studies by Landé 1965 and Cushner 1976.

16 One example is what happened in the elections held in Balayan, Batangas, in 1892, when the civil governor of Manila proposed the appointment of a candidate who did not speak Castilian as mayor, an appointment that was subsequently ratified by the governor-general of the Philippines. See Inarejos 2011.

17 In general, successive attempts at promoting literacy emanating from the mother country were hampered by the religious orders. Due to this language gap, the religious orders became key interlocutors between Spanish colonial authorities and the indigenous population because of their command of native languages, as has been documented by Rafael 1993, 2005.

18 The family played a central role in the articulation of social relations and competition among elites to achieve political and socioeconomic dominance, a competition whose patterns had 
persisted throughout the twentieth century. See, among others, Machado 1974; Anderson 1988; McCoy 2002.

19 This ruse was often used during the elections that took place in the nineteenth-century metropolis, as I was able to corroborate in Inarejos 2008, 224-25.

20 This position was created in 1885 during the term of Governor-General Weyler. It constituted, together with the establishment of civil governments and the extension of the peninsular penal code to the colony, one more of the assimilationist reforms undertaken during the final quarter of the century. See Marimón 1994, 102.

21 For more on the low diffusion of Castilian in the Philippines, see Rafael 2005

22 The term rancherías was used to describe villages and hamlets set at some distance away from the established towns. The populations of these seminomadic villages were the favorite targets of a settlement policy aimed at increasing tax collection and conversion to Christianity. See Blanco 2009, 45.

23 The agent of the tobacco monopoly held an influential position, which, despite the abolition of the monopoly on tobacco, enabled officials to engage in various irregularities related to personal services; see De Jesus 1980, 120

24 Batangas was one of the best known provinces where a third of the local economic elites, which led either parties or factions and vied for power in the localities of the province between 1887 and 1894, directly assumed the role of gobernadorcillo, while the other posts were controlled by proxies, clients, or lieutenants (May 1991, 33). Cf. May 1987. However, the significance of this fact varied greatly. The geography of the province and its relative wealth were factors in the evident contrast between the prevailing interest in Pampanga and the notorious disinterest shown in Nueva Ecija. The rural-urban variable was evident in Manila, with the exception of thei importance within the Chinese community, where there was widespread displeasure associated with assuming these offices, contrary to what generally occurred in the countryside, as Huetz de Lemps 1997 has shown systematically.

25 The baptismal certificate certified that Carlos González was born in Agoo (a locality that was later called San Isidro de Tubao) on 1 Feb. 1861, son of Santiago González, a European Spaniard (native of María, Zaragoza province), and the native María Merced Fontanilla. Carlos González was baptized by the Augustinian friar Valentín Pérez, curate of Santo Tomás; his godfather was Francisco de Paula Martínez, parish priest of Agoo.

26 The Filipinos found themselves in an even lower status than the Cubans, who gained access to higher levels of self-government in the course of the nineteenth century. For a detailed analysis of this legislation, in comparison with the Cuban case, see Dunerin 1978 and Fradera 2005

27 Alongside the political exclusions contained in the special laws mentioned above, it suffices to recall the constraints imposed by the ecclesiastical authorities, especially by the omnipotent regular orders, on the progressive incorporation of a native secular clergy into their ranks, a concern that only increased after the alleged participation of various native priests in a revolt in Cavite in 1872. However, a native secular clergy was one of the weapons to which bishops, archbishops, or captains general often resorted to counter the unbridled power of those orders. Something similar happened in the army, whose officer corps were reserved for Spaniards. To avoid mentioning here a hodgepodge of citations, see Elizalde 2009a for a recent exhaustive review of the literature concerning the organization of political, religious, and socioeconomic power in the Philippines.
28 This is in line with the prescriptions proffered by Sinibaldo de Mas in the mid-nineteenth century to reduce the Creole population to "as low as possible" in his Informe sobre el Estado de las Islas Filipinas en 1842, cited by Blanco 2009, 87.

29 This contradiction is laid out in Saada 2007

30 On Chinese mestizos, see the classic works of Wickberg 1964, 1965.

31 A burgeoning of social forces and the consequent imperial policies that sought to contain them are two aspects that demand further study, according to both Fradera $(2005,682)$ and Elizalde (2009b, 68).

32 This was a calculated obfuscation categorized by Huetz de Lemps 2009 as "a weapon of colonial control."

33 The two gobernadorcillos who preceded Buenaventura Dacanay were Felipe Llorens and Santiago Vetía.

34 Much the same occurred in other imperial contexts as with the British at similar stages, as demonstrated by Engels and Marks 1994

35 For a successful critical review of these prejudices, see Guha 2002

36 Roberto Blanco $(2004,591)$ has delved into the warnings raised by the regular clergy regarding conspiracy plots, which were discussed in detail in the letters of various curates to the captain general ahead of the uprising of 1896.

37 This uprising of 1884, despite its local character, led to the arrest of prominent Filipinos who aroused the suspicions of the colonial authorities in the other provinces, according to Schumacher 1973.

38 These confrontations, because of their supposed connection to the priest, led to the marginalization of municipal offices, as confirmed by Foreman $(1906 / 1985,205)$, or to deportation, which was common situation according to Bankoff (1992, 686-87): "The real extent of the priest's authority, however, depended upon his ability to denounce a person as morally or politically suspect and thus have him deported without trial or sentence to an agricultural colony on Mindanao or some other island."

39 This value judgment of the religious clergy constituted a representative sample of a widely held belief among Spaniards that Filipinos were uncivilized. A similar perspective was adopted by the British, French, and Dutch in their Asian colonies, and prejudices imbued with social Darwinism that were brought to bear when the time came to justify colonial rule. These contradictory aspects are unraveled in Singh Mehta 1999; Pitts 2005; Bertrand 2005.

40 This dovetails with the complicity, tolerance, and lack of consequential influence, as explained by Huetz de Lemps 2006, when tackling the entrenched corruption of the Philippine colonial administration.

41 Although the fate of José María Osorio is not known after his replacement as the civil governor of La Unión, it has been speculated that he was assigned to another province. A common procedure in the metropolis involving governors accused of orchestrating electoral irregularities was to expose them to the scorn of public opinion, but when their vices had wider repercussions they were punished with largely symbolic reprisals.

42 Parallel to strengthening the position of gobernadorcillo, with the reforms of 1893 the head of the barangay assumed the former duties of the village lieutenant. 
43 The electorate was comprised of the following barangay heads: Alberto Boadoy (40 votes), Emeterio Padilla (40 votes), Guillermo Portes (45 votes), Torcuato Gago (44 votes), Dámaso Suguitán (36 votes), Florentino Milans (31 votes); in the category of former captains or gobernadorcillos were Buenaventura Dacanay (53 votes), Felipe Llorens (48 votes), and Santiago Vetía (37 votes); and as major contributors Felipe Santiago González (59 votes), Anselmo García (58 votes), and Bernardo Dacanay (31 votes).

44 This was a recurrent and arbitrary procedure adopted in the metropolis during much of the nineteenth century, aided by the identification of the small number of voters entitled to vote until the definitive establishment of universal suffrage. When the number of electors in opposition was large, the procedure often resulted in the displacement or detention of any candidate who threatened electoral resistance to the official or ministerial candidate in order to prevent him from mounting an electoral campaign in his district and mobilizing his supporters.

\section{References}

Alonso, Luis. 2009. La administración española en las islas Filipinas, 1565-1816. Algunas notas explicativas acerca de su prolongada duración. In Repensar Filipinas. Política, identidad y religión en la construcción de la nación Filipina, ed. Ma. Dolores Elizalde, 79-117. Barcelona: Edicions Bellaterra.

Alvarado, Javier. 2001. Constitucionalismo y codificación en las provincias de Ultramar. La supervivencia del Antiguo Régimen en la España del siglo XIX. Madrid: CEPC.

Anderson, Benedict. 1988. Cacique democracy in the Philippines: Origins and dreams. New Left Review I/169 (May-June): 3-31.

Azcárraga y Palmero, Manuel de. 1871. La reforma del municipio indígena en Filipinas. Madrid: J. Noguera.

Bankoff, Greg. 1992. Big fish in small ponds: The exercise of power in a nineteenth-century Philippine municipality. Modern Asian Studies 26(4): 679-700.

Bertrand, Romain. 2005. État colonial, noblesse et nationalisme à Java. La Tradition parfait [Colonial state, nobility and nationalism in Java. The perfect tradition]. Paris: Karthala.

Blanco, John David. 2009. Frontier constitutions: Christianity and colonial empire in the nineteenthcentury Philippines. Berkeley: University of California Press.

Blanco, Roberto. 2004. Las órdenes religiosas y la crisis de Filipinas. Hispania Sacra 56:583-614.

Blumentritt, Ferdinand. 1881. Organisation communale des indigènes des Philippines placées sous la domination espagnole [Communal organization of the natives of the Philippines under Spanish rule]. Paris: Bulletin de la Société Académique Indo-Chinoise.

Castellanos, Alicia. 1998. Filipinas. De la insurrección a la intervención de EE UU. Madrid: Sílex.

Celdrán, Julia. 1994. Instituciones Hispanofilipinas del siglo XIX. Madrid: MAPFRE.

Chatterjee, Partha. 1993. The nation and its fragments: Colonial and postcolonial histories. Princeton: Princeton University Press.

Cushner, Nicholas. 1976. Landed estates in the Philippines: From conquest to revolution. New Haven: Southeast Asia Studies, Yale University.
De Jesus, Edilberto C. 1978. Gobernadorcillo elections in Cagayan. Philippine Studies 26(1): $142-56$.

1980. The tobacco monopoly in the Philippines. Bureaucratic enterprise and social change, 1776-1880. Quezon City: Ateneo de Manila University Press.

Dunerin, James. 1978. Maura et Cuba. Politique coloniale d'un ministre libéral [Maura and Cuba: Colonial policy of a liberal minister]. Paris: Les Belles Lettres, Annales Littéraires de l'Université de Besançon.

Elizalde, Ma. Dolores. 2002. La administración colonial de Filipinas en el último tercio del XIX. Dos procesos contrapuestos: La reactivación del interés español frente a la consolidación de una identidad nacional filipina. In Las relaciones entre España y Filipinas, siglos XVI-XX, ed. Ma. Dolores Elizalde, 123-42. Madrid: CSIC-Casa Asia.

2008. Filipinas, ¿una colonia internacional? Illes i Imperis 10-11:203-36.

_ ed. 2009a. Repensar Filipinas: Política, identidad y religión en la construcción de la nación filipina. Barcelona: Bellaterra.

- 2009b. Sentido y rentabilidad: Filipinas en el marco del imperio español. In Repensar Filipinas. Política, identidad y religión en la construcción de la nación filipina, ed. Ma. Dolores Elizalde, 45-78. Barcelona: Bellaterra.

Engels, Dagmar and Shula Marks, eds. 1994. Contesting colonial hegemony: State and society in Africa and India. London: British Academy Press.

Foreman, John. 1906/1985. The Philippine islands. 3d ed. Reprint, Mandaluyong City: Cacho Hermanos.

Fradera, Josep María. 1999. Filipinas, la colonia más peculiar. La hacienda pública en la definición de la política colonial, 1762-1868. Madrid: CSIC.

2005. Colonias para después de un imperio. Barcelona: Bellaterra.

—. 2008. La nación desde los márgenes (Ciudadanía y formas de exclusión en los imperios). Illes i Imperis 10-11:9-30.

Guha, Ranajit. 2002. Las voces de la historia y otros estudios subalternos. Barcelona: Crítica.

Hidalgo, Patricio. 1995. Encomienda, tributo y trabajo en Filipinas (1570-1608). Madrid: Ediciones Polifemo/Universidad Autónoma de Madrid.

Huetz de Lemps, Xavier. 1997. La crise de la commune indigène a Manille au XIXe siècle [The crisis of the indigenous town in Manila in the nineteenth century]. In El lejano oriente español: Filipinas (siglo XIX), ed. Paulino Castañeda and Antonio F. García-Abásolo, 419-42. Sevilla: Cátedra General Castaños.

—. 1998a. Nommer la ville: les usages et les enjeux du toponyme «Manila» au XIXe siècle [Name the city: Uses and challenges of the name "Manila" in the nineteenth century]. Genèses 33:28-48.

. 1998b. Territorio y urbanismo en las Islas Filipinas en el entorno de 1898. Ciudad y Territorio 30(116): 381-428

_ 2006. L'Archipel des épices : La corruption de l'Administration espagnole aux Philippines (fin $X V I I I e-f i n X I X e$ siècle) [The archipelago of spices: The corruption of the Spanish administration in the Philippines in late eighteenth-late nineteenth century]. Madrid: Casa de Velázquez. 
2009. Una escuela colonial de disimulación. In Repensar Filipinas. Política, identidad y religión en la construcción de la nación filipina, ed. Ma. Dolores Elizalde, 143-56. Barcelona: Bellaterra.

Inarejos, Juan Antonio. 2008. Ciudadanos, propietarios y electores en la construcción del liberalismo español. El caso de las provincias castellano-manchegas (1854-1868). Madrid: Biblioteca Nueva.

2011. Reclutar caciques. La selección de las élites colonials Filipinas a finales del siglo XIX. Hispania 71(239): 741-62.

Landé, Carl. 1965. Leaders, factions, and parties: The structure of Philippine politics. New Haven: Yale University Press.

Machado, K. G. 1974. From traditional faction to machine: Changing patterns of political leadership and organization in the rural Philippines. Journal of Asian Studies 33:523-47.

Marimón, Antoni. 1994. La política colonial d'Antoni Maura. Les colònies espanyoles de Cuba, Puerto Rico i les Filipines a finals del segle XIX [The colonial policy of Antonio Maura. The Spanish colonies of Cuba, Puerto Rico, and the Philippines in the late nineteenth century]. Palma: Edicions Documenta Balear.

—. 1996. Las reformas de Antonio Maura, ministro de Ultramar (1892-1894), en las islas Filipinas. In Antes del "desastre": Orígenes y antecedentes de la crisis del 98, ed. Juan Pablo Fusi Aizpurúa and Antonio Niño Rodríguez, 243-52. Madrid: Departamento de Historia Contemporánea, Universidad Complutense de Madrid.

May, Glenn Anthony. 1987. Civic ritual and political reality: Municipal elections in the late-19thcentury Philippines. In A past recovered, Glenn Anthony May, 30-52. Quezon City: New Day.

- 1991. Battle for Batangas: A Philippine province at war. New Haven: Yale University Press.

McCoy, Alfred, ed. 2002. An anarchy of families: State and family in the Philippines. Quezon City: Ateneo de Manila University Press.

Owen, Norman G. 1974. The principalia in Philippine history: Kabikolan, 1790-1898. Philippine Studies 22(3-4): 297-324.

Pastor, Luis María. 1860. La política que expira y la política que nace. Madrid: Imprenta de M. Galiano.

-1863. Las elecciones, sus vicios. La influencia moral del Gobierno. Estadísticas de la misma y proyecto de reforma electoral. Madrid: Imprenta Sáez.

Pitts, Jennifer. 2005. A turn to empire: The rise of imperial liberalism in Britain and France. Princeton: Princeton University Press.

Rafael, Vicente L. 1993. Contracting colonialism: Translation and Christian conversion in Tagalog society under early Spanish rule. Durham: Duke University Press.

2005. The promise of the foreign: Nationalism and the technics of translation in the Spanish Philippines. Durham: Duke University Press.

Rodrigo, Martín. 2002. Los intereses empresariales españoles en Filipinas. In Las relaciones entre España y Filipinas, siglos XVI-XX, ed. Ma. Dolores Elizalde, 123-42. Madrid: CSIC-Casa Asia.

Saada, Emmanuelle. 2007. Les enfants de la colonie. Les métis de l'Empire français entre sujétion et citoyenneté [The children of the colony: The mestizos of the French empire between subjection and citizenship]. Paris: Éditions La Découverte.
Sánchez, Luis Ángel. 1989. Elecciones locales indígenas en Filipinas durante la etapa hispánica. In Estudios sobre Filipinas y las islas del Pacífico, ed. Florentino Rodao, 53-61. Madrid: Asociación Española de Estudios del Pacífico.

- 1990. Estructura de los pueblos de Indios en Filipinas durante la época española. In España y el Pacífico, ed. Florentino Rodao, 81-116. Madrid: Agencia Española de Cooperación Internacional.

_. 1991. Las principalías indígenas y la administración española en Filipinas. Madrid: Universidad Complutense de Madrid.

Schumacher, John. 1973. The propaganda movement: 1880-1895. The creators of a Filipino consciousness, the makers of the revolution. Manila: Solidaridad Publishing House.

Singh Mehta, Uday. 1999. Liberalism and empire: A study in nineteenth-century British liberal thought. Chicago: University of Chicago Press.

Trocki, Carl. 2004. Political structures in the nineteenth and early twentieth centuries. In The Cambridge history of Southeast Asia, ed. Nicholas Tarling, vol. 3, 75-126. 3d ed. Cambridge: Cambridge University Press.

Wickberg, Edgar. 1964. The Chinese mestizo in Philippine history. Journal of Southeast Asian History $5(1): 62-100$.

_. 1965. The Chinese in Philippine life (1850-1898). New Haven: Yale University Press.

Juan Antonio Inarejos is a postdoctoral researcher at the Instituto de Historia, Calle Albasanz, 26-28, 2a Planta, Consejo Superior de Investigaciones Científicas (CSIC), 28037 Madrid, Spain. He is the author of three books on Spanish liberalism and the foreign and colonial policy of Spain in the mid-nineteenth century. <juan.inarejos@cchs.csic.es> 
